\title{
The Impact of Educational Concerns and Satisfaction on Baccalaureate Nursing Students' Distress and Quality of Life During the Covid-19 Pandemic. A Cross-Sectional Study
}

Tone Nygaard Flølo ( $\nabla$ tonenyga@oslomet.no )

Oslo Metropolitan University

Kari Hanne Gjeilo

NTNU, Norwegian University of Science and Technology

John Roger Andersen

Western Norway University of Applied Sciences

Kristin Haraldstad

University of Agder

Inger Helene Hardeland Hjelmeland

Western Norway University of Applied Sciences

Marjolein Memelink Iversen

Western Norway University of Applied Sciences

Borghild Løyland

Oslo Metropolitan University

Tone Merete Norekvål

Western Norway University of Applied Sciences

Kirsti Riiser

Oslo Metropolitan University

Gudrun Rohde

University of Agder

Kristin Hjortland Urstad

University of Stavanger

Inger Utne

Oslo Metropolitan University

Elisabeth Grov Beisland

Western Norway University of Applied Sciences

Research Article 
Keywords: Student satisfaction, academic quality concerns, quality of life, psychological distress, nursing students

Posted Date: December 9th, 2021

DOI: https://doi.org/10.21203/rs.3.rs-1138275/v1

License: (1) This work is licensed under a Creative Commons Attribution 4.0 International License. Read Full License 


\section{Abstract}

\section{Background}

High levels of psychological distress and poor overall quality of life (QOL) have been identified among nursing students during the COVID-19 pandemic. The pandemic necessitated improvised reconstructions of educational curriculums and restrictions in clinical placement and training at campuses, possibly reducing educational quality.

\section{Objectives}

We explored whether baccalaureate nursing students' concerns and satisfaction with the educational curriculum, focusing on the conduct of clinical training, were associated with perceived psychological distress and overall QOL.

\section{Methods}

Baccalaureate nursing students $(\mathrm{N}=6088)$ from five Norwegian universities were invited to an internetbased, cross-sectional survey during the second wave of the pandemic. The survey included COVID-19 specific questions on health, education and clinical training, the Fear of COVID-19 scale (FCV-19S), The Hopkins Symptom Checklist (SCL-5) and overall QOL. Data from national surveys on satisfaction with the educational curriculum, before and during the pandemic were used for comparison.

\section{Results}

In total, 2605 (43\%) students responded, of whom 1591 (61\%) had been engaged in clinical training during the pandemic. Overall, $53 \%$ were either satisfied or fully satisfied with their educational curriculum, with the level of satisfaction being significantly lower than pre-pandemic reference values. Also, $79 \%$ were concerned or highly concerned about the educational quality. In multiple regression analyses for all students, lower levels of satisfaction and higher levels of quality concerns were associated with worse SCL-5 scores. Furthermore, satisfaction with the educational curriculum was positively associated with overall QOL. For students engaged in clinical training, only concerns about infecting others were additionally associated with psychological distress. None of the items related to clinical training were associated with overall QOL.

\section{Conclusion}

Nursing students' educational satisfaction and quality concerns may significantly impact perceived psychological distress and overall QOL during a pandemic. However, with necessary adaptations implemented, concerns regarding the conduct of clinical training account for little of these associations.

\section{Introduction}


During the coronavirus disease 2019 (COVID-19) pandemic, elevated levels of psychological distress and reduced overall quality of life (QOL) have been identified among students in higher education, globally and in Norway [1-3]. A Norwegian survey during the pandemic found a general decline in measures of life-satisfaction and mental health with young adults and students more severely affected [4]. Yet, we recently observed that fear of COVID-19 in Norwegian nursing students accounted for only minor parts of the deteriorated psychological health and overall QOL [3], suggesting that other factors related to being a student during a pandemic may contribute to the observed changes. Identifying education-related predictors of students' well-being throughout the course of the pandemic may be important for adequate handling of restrictions in higher education institutions.

An educational process is recognized as a high-stress period [5], and psychological distress may lead to poor academic performance [6, 7]. For instance, in undergraduate students prior to the COVID-19 crisis, academic performance, pressure to succeed, and post-graduation plans were the students' top three concerns [8]. For nursing students in particular, psychological distress has been identified to negatively impact QOL, educational and clinical training performance [9].

For educational institutions, the pandemic necessitated improvised reconstructions of curriculums, rapid move to online distance learning, and restrictions in practical placement or simulation training both in and outside of campuses, all possibly inducing additional stress [10]. Thus, finding ways to mitigate psychological distress and sustain overall QOL may benefit students' learning and the society's need for competent future professionals.

Student satisfaction has gained global attention as a measure of effectiveness of educational curriculums [11]. Instructional effectiveness, student support facilities, internet and library access, administrative staff efficiency, university environment, and student characteristics such as gender, ethnicity, and age are all factors identified to impact overall student satisfaction in higher education [1215]. Furthermore, empirical analysis and deconstruction of the concept student satisfaction suggest academic and pedagogic quality of teaching to be crucial determinants of student satisfaction, potentially overlapping with students' assessment of teaching [16].

Nursing students may face higher levels of stress than other health professional students, even under normal circumstances $[17,18]$ and may therefore be particularly vulnerable to educational constraints resulting from measures to restrict spread of COVID-19. The conduct of clinical training, essential in all nursing educations and accounting for up to $50 \%$ of most European and international curriculums [19, 20] may be particularly difficult during a pandemic. For a three-year baccalaureate education, restrictions beginning in March 2020 will for some students have been operative for up to half of the educational period. Hence, nursing students expressed concerns about interruptions in their clinical training and how these would affect overall quality of education and post-graduation careers [21].

The purpose of this study was first to determine baccalaureate nursing students' satisfaction with their educational curriculum during the COVID-19 pandemic, compared to pre-pandemic reference data. 
Second, we investigated how students' satisfaction was related to concerns about the education quality, and finally how these two measures were associated with psychological distress and overall QOL.

\section{Methods}

\section{Setting and design}

Full- and part-time baccalaureate nursing students $(\mathrm{N}=6088)$ from five Norwegian universities at ten campuses were invited to participate in an internet-based cross-sectional survey from January $27^{\text {th }}$ to February $28^{\text {th }} 2021$, at the peak of the second wave of the pandemic in Norway. Participating universities were the Norwegian University of Science and Technology, University of Agder, University of Stavanger, Western Norway University of Applied Sciences and Oslo Metropolitan University. Detailed information about study setting, design and data collection were recently published [3]. Two national surveys on satisfaction with the educational curriculum were used for comparison: The National Students Survey 2019 (pre-pandemic results) and The National Students Survey 2020 (October 2020 prior to the second pandemic wave in Norway) [22].

\section{Measures}

Respondents provided information on study site, year of study, age, and household status. The complete survey included COVID-19 specific questions related to health, education and clinical training, the Fear of COVID-19 scale (FCV-19S), the Hopkins Symptom Checklist (SCL-5) and overall quality of life (QOL) [2325]. Additional COVID-19 specific questions about students' concerns related to clinical training during societal lockdown were collected only from students who engaged in such training.

Feasibility pilot studies of the complete questionnaire as well as content and validity of all included questionnaires and COVID-19-specific items are detailed previously [3]. Psychological distress was measured with the SCL-5, encompassing five items rated on a scale from 1 "not at all" to 5 "extremely" $[23,26]$. Average item score was determined by dividing total score by number of items answered [27]. Higher scores indicate greater psychological distress. Overall QOL was captured by one question, All in all, how satisfied are you with your life at this time?, representing an adapted version of the Cantril Ladder [24]. Answers were scored from 0 (not at all satisfied) to 10 (highly satisfied), with scores of 6 or more indicating high life satisfaction [28].

Specific to the present analysis, global satisfaction with the educational curriculum was measured with one item retrieved from the Norwegian National Student Survey, I am, overall, satisfied with the curriculum I am currently attending [22]. Concerns about the quality of the education were measured with one item, Due to the COVID-19 pandemic I am concerned that the quality of my education will be poorer than it would otherwise have been. Additional questions were related to the conduct of clinical training and placements and included the students' perceived risk of being infected with COVID-19, necessary knowledge of infection control, concerns about infecting others, concerns about absenteeism, concerns about completion, experience of fewer learning situations and experience with insufficient guidance. 
Responses to all these questions were rated from 1 (strongly disagree) to 5 (strongly agree). Further, the students were asked if they had been in self-imposed quarantine during the pandemic.

\section{Ethics}

Participating students consented by completing and submitting the electronic survey in "SurveyXact" (https://www.surveyxact.com/). Their answers were stored anonymously, hence ethical approval was not required according to Norwegian legislation. However, the Data Protection Officer at Western Norway University of Applied Sciences evaluated the survey, and additional approvement was obtained from each University.

\section{Statistics}

Categorical variables are expressed as numbers and percentages, and continuous variables as means and standard deviations (SD). Mean scores for satisfaction with the curriculum were available from 2019 (prior to the COVID-19 pandemic) and from October/November 2020 (prior to/at the beginning of the second wave of the pandemic) for nursing students at the five participating universities [22]. For comparison, the mean scores were adjusted according to the relative contribution of each university in the present study, and compared using one sample t-test [29]. For binary logistic regression analysis, satisfaction with the curriculum and concerns about the quality of the education were dichotomized and used as dependent variables. Variables with univariate significant associations were entered in multivariate analyses and results expressed as odds ratios (OR) and 95\% confidence intervals $(\mathrm{Cl})$. Level of explained variance in the models were expressed as Nagelkerke pseudo- $\mathrm{R}^{2}$ values. Hierarchical regression analyses, with study site as clusters, were conducted to investigate the impact of satisfaction and quality concerns on SCL-5 and QOL used as z-transformed continuous variables. Variables previously identified to be independently associated with either SCL-5 or QOL were entered in the models together with satisfaction and concerns related to the education, both used in their original 5-point ordinal scale.

Both binary logistic and linear hierarchical regression analyses were performed first on all students. The analyses were repeated for students who engaged in clinical training during the societal lock-down with COVID-19 specific questions included as independent variables.

In the hierarchical regression analyses, effect-size of the associations were interpreted from the change in the dependent variable per 2 SD changes in FCV-19S or between respondents representing the lower or higher end of the discrete variables with 2-5 categories [30, 31]. In t-tests, the effect-size was estimated as Cohen's $d$ [32]. Overall, effect-sizes were interpreted as follows: trivial $(<0.2)$, small $(0.2$ to $<0.5)$, moderate $(0.5$ to $<0.8)$ and large $(\geq 0.8)$. All tests were two-sided and $p$-values below 0.05 were considered significant.

\section{Results}


In total, 2605 of the 6088 students responded to the survey, yielding a response rate of $43 \%$, differing between the universities from 21 to $50 \%$. Among these, 1591 (61\%) reported to have been engaged in clinical training, either in primary or specialist care, including community-based and institutional services, during the pandemic.

\section{Respondents' satisfaction with their educational curriculum}

Overall, $54 \%$ of the students were either satisfied $(n=1108,43 \%)$ or fully satisfied $(n=274,11 \%)$ with their curriculum (Table 1). The proportion of either satisfied of fully satisfied students varied from 42 to $72 \%$ among the five participating universities. The mean score for the whole group of respondents was 3.40 (SD 1.01). Compared to the adjusted mean score for satisfaction obtained for bachelor nursing students at the same universities in 2019 (3.74) and in October/November 2020 (3.82) the mean score of the respondents was $0.34(p<0.001)$ and $0.42(p<0.001)$ lower, both corresponding to small effect-sizes.

For logistic regression analyses satisfaction was dichotomized into low (response levels 1-3) and high (levels 4-5, Table 1). In multivariate analysis including all students, study site, the level of trust in universities' handling of the COVID-19 situation (strongly agree versus strongly disagree, OR 61.3) and concerns about the quality of the education during the pandemic (disagree versus strongly agree, OR 4.5) were significantly associated with the level of satisfaction. There was no difference between students engaged in clinical training during the pandemic and those not involved (OR 1.042, $p=0.689)$. The Nagelkerke pseudo- ${ }^{2}$ value for the final model was 0.41 .

To explore the added significance of students' experience during clinical training, the eight thereto related questions were added in analyses for the 1591 respondents engaged in clinical training during the pandemic. Again, there were significant associations with study site, trust in the institutions' handling (strongly agree versus strongly disagree, OR 164.9) and quality concerns (strongly disagree versus strongly agree, OR 3.6). Items related to clinical training, and significantly associated with satisfaction, were concerns about absenteeism (disagree versus strongly agree, OR 3.0) and the experience of fewer learning situations (neither agree nor disagree versus strongly agree, OR 2.3). The Nagelkerke pseudo- $\mathrm{R}^{2}$ value for the final model in the subset of students with clinical training, increased to 0.44 .

Sensitivity analyses using an alternative dichotomization (1-2 versus 3-5) gave essentially identical results.

\section{Respondents' concerns about the quality of education during the pandemic.}

Overall, $79 \%$ of the students reported to be concerned $(n=869,33 \%)$ or highly concerned $(n=1196,46 \%)$ about the educational quality during the pandemic (Table 2). The proportion of concerned or highly concerned nursing students ranged from $70 \%$ to $82 \%$ between universities.

For logistic regression analyses of factors associated with level of concern, the responses were dichotomized into low (1-3) and high (4-5, Table 2). For all students, study site, year of study (third year 
versus first, OR 0.42), age (oldest versus youngest category, OR 0.59), the level of trust in universities' handling of the COVID-19 situation (strongly agree versus strongly disagree, OR 0.3 ), feeling of loneliness (strongly agree versus strongly disagree, OR 5.2) and satisfaction with the curriculum (disagree versus strongly agree, OR 5.2) were significant in multivariate analysis, for a Nagelkerke pseudo- $\mathrm{R}^{2}$ value of 0.25 . There was no difference between students engaged in clinical practice during the pandemic and those not involved (OR 0.773, $p=0.150)$.

Adding the questions related to clinical training during the pandemic, the logistic regression analyses were repeated for the 1591 respondents engaged in clinical training. Again, in multivariate analysis, there were significant associations with study site, year of study (third year versus first, OR 0.32), trust in the institutions' handling (strongly agree versus strongly disagree, OR 0.28), feeling of loneliness (strongly agree versus strongly disagree, OR 5.6) and satisfaction (disagree versus strongly agree, OR 3.9). All items related to clinical training were univariately associated with quality concerns, but only concerns for completion of clinical training (disagree versus strongly agree, OR 0.24) and the experience of fewer learning situations (strongly disagree versus strongly agree, OR 0.13 ) retained significance in multivariate analysis. The Nagelkerke pseudo- $R^{2}$ value for the final model in the subset of students with clinical training increased to 0.37 .

Sensitivity analyses using alternative dichotomization (1-4 versus 5) gave similar results.

\section{Impact of satisfaction and quality concerns on psychological distress}

The association of student reported satisfaction with the educational curriculum and concerns about the quality of the nursing education on SCL-5 scores, were explored in all students and those engaged in clinical training during the pandemic. The hierarchical regression models using SCL- 5 scores as the dependent variable for all students is presented in Table 3. For all students, both satisfaction (effect-size for strongly disagree versus strongly agree $=0.39, p<0.001$ ) and quality concerns (effect-size for strongly disagree versus strongly agree $=0.17, p=0.031$ ) were significantly associated with SCL-5 scores, i.e. lower levels of satisfaction and higher levels of concerns were associated with worse SCL-5 scores. For students involved in clinical training during the pandemic, including additionally items related to clinical training in the model, only satisfaction retained significance (effect-size for strongly disagree versus strongly agree $=0.36, p=0.007$ ), whereas the level of concerns was not associated (effect-size $0.12, p=$ 0.508 , data not shown). Of the eight items related to clinical training, concerns about infecting others during training was positively and significantly associated with SCL-5 (effect-size for neither disagree nor agree versus strongly agree $=0.26, p=0.005$, data not shown).

\section{Impact of satisfaction and quality concerns on quality of life}

Similarly, the association of student reported satisfaction and concerns about educational quality on QOL were explored in all students and those engaged in clinical training in two separate hierarchical regression models. For all students, satisfaction with the curriculum was positively and significantly associated with QOL (effect-size for strongly disagree versus strongly agree $=0.87, p<0.001$, Table 3 ). For 
students involved in clinical training during the pandemic, satisfaction retained a significant association (effect-size $0.85, p<0.001$ ), whereas neither educational concerns nor any of the items related to clinical training were associated with QOL (data not shown).

\section{Discussion}

At the peak of the second wave of the COVID-19 pandemic, we investigated Norwegian baccalaureate nursing students' satisfaction with their educational curriculum and their concerns about the quality of their education, with emphasis on the conduct of clinical training. Compared to pre-pandemic reference data from the same institutions, satisfaction was lower, but with a small effect-size. Most students reported to be concerned about the quality of their education, influenced also by worries about conduct of clinical training. Satisfaction and concerns about quality were strongly associated with trust in universities' handling of the pandemic. Educational satisfaction positively affected overall QOL, and to a lesser degree, psychological health, whereas concerns about quality only affected psychological health.

We aimed to determine educational factors that could explain reduced overall QOL and increased psychological distress, previously demonstrated in nursing students during the second wave of COVID-19 in Norway [3]. This analysis was prompted by findings that fear of COVID-19 was strongly associated with psychological distress, but only moderately accounted for the decrease in overall QOL in these students. Assessed by one claim, I am, overall, satisfied with the curriculum I am currently attending, we chose to evaluate satisfaction as it has been used in an identical manner in Norwegian students for many years prior to the pandemic, and representative data was available for comparison [22]. A major finding of our study was the relatively small decline in student satisfaction from pre-covid reference levels. Others have also analyzed nursing students' level of satisfaction during the pandemic, mostly satisfaction with remote learning [33,34] or imposed changes in clinical placement [34], but without comparisons to pre-pandemic levels of overall satisfaction.

We found trust in universities' handling of the pandemic to be the major determinant of satisfaction, complying with studies suggesting that universities' instructional effectiveness and student support facilities may influence overall satisfaction under normal circumstances [11, 14, 15]. Our data suggest that building trust may be important and that measures taken during a crisis need to be clear and understandable to sustain satisfaction. When analyzing satisfaction of nursing students with remote learning situations specifically, also institutions/'instructors' attitudes towards these teaching situations and optimal use of technology were main determinants of satisfaction during the pandemic [33]. Thus, institutional handling of the pandemic, as any future crisis affecting nursing education, seems to play a major role in maintaining satisfaction.

Students' satisfaction with the curriculum has attracted interest in research of higher education even before the COVID-19 pandemic [11,35]. Satisfaction of undergraduate nursing students is important both for attracting students to a health profession, for their motivation to complete the education and enter a professional career as much needed nurses [36]. Of interest, the perceived quality of the education, and 
by inversion, concerns about a lack thereof, have been invoked as one of several factors influencing satisfaction [16]. Unfortunately, to our knowledge, no data with a similar question as ours, Due to the COVID-19 pandemic I am concerned that the quality of my education will be poorer than it would otherwise have been, is available to directly assess the level of change in worries that nursing students have experienced because of the pandemic. We found however, that in addition to a major impact of trust in universities' handling of the COVID-19 crisis, concerns about overall educational quality were associated with satisfaction. With $61 \%$ of students in our sample having participated in at least some clinical training during the pandemic, their concern about the conduct of this activity affected the overall educational satisfaction only to a small extent (increase in explained variance of the models, Nagelkerke pseudo $\mathrm{R}^{2}$, from 0.41 to 0.44 ). This may have to do with policies adopted by Norwegian universities, where clinical training in nursing homes and hospitals continued with precautionary regulations even before large-scale vaccination of the elderly population and health care professionals occurred. This reassuring finding of ours contrasts others where concerns about the clinical training have impacted overall perception of their education [37]. This may not come as a surprise since it may be particularly difficult to replace face-to-face "hands-on" training during a pandemic [34, 38]. Furthermore, higher levels of concern reported in first year students suggest better strategies may be needed to take care of certain groups of students. A Danish study of health profession students also reported young age, female sex and enrollment in baccalaureate curriculums to be associated with higher levels of educational stress during the pandemic, all characteristics typical for undergraduate nursing students [10].

In our sample, satisfaction with the educational curriculum was associated with overall QOL with a large effect-size in regression models, to an extent comparable with the effect of loneliness [3]. The effect of satisfaction on psychological distress was lower in magnitude, but these findings together indicate that universities may contribute to nursing students overall QOL, and thereby possibly to their academic performance. Efforts to build effective curriculums of high academic quality seem to be important, especially during a crisis. Overall concerns and those specifically related to disruptions of clinical training, were associated only with psychological distress. Thus, nursing students' concerns about the educational quality seem to target specifically the conduct of education and does not affect the more general level of QOL in our sample.

The pandemic appeared to wane before another powerful wave of contagion recently hit the world. Nevertheless, at some point students' lives will return to a new state of normal where educational curriculums begin to transit back to the modalities previously used. Thus, time is due for institutions of higher education to consider structures and strategies that support students' psychological health and educational trajectory during current and future pandemics or similar crises. In this regard, findings from the present study suggest trustworthy institutional handling to be an important area of effort to improve student satisfaction and reduce educational quality concerns.

\section{Strengths and limitations}


The present survey is based on cross-sectional data and does not allow assessments of change over time at an individual level. However, available reference data derived from two National Student Surveys (prior to and between the first and second wave of the COVID-19 pandemic) [22] add strength to our study by providing measures of student satisfaction at three different time-points for comparison.

Furthermore, the large sample of baccalaureate nursing students from universities using a curriculum comparable to most European and many international recommendations [19], increases the external validity of our findings. The narrow focus on clinical training, not covering other COVID-19 related educational changes, for example students' perceptions of transition to digital learning, represents a limitation of our study.

\section{Conclusion}

Baccalaureate nursing students' satisfaction and concerns about educational quality were strongly associated with trust in universities' handling of the pandemic. Overall level of concern about the quality was moderately affected by concerns related to the conduct of clinical training, whereas student satisfaction was not. Furthermore, students' satisfaction may significantly impact perceived overall QOL, and to a lesser degree, psychosocial health, whereas concerns about quality only affected psychological health.

\section{Declarations}

\section{Ethics approval and consent to participate}

Participating students consented by completing and submitting the electronic survey in "SurveyXact" (https://www.surveyxact.com/). Their answers were collected and stored anonymously, hence ethical approval was not required according to the Act relating to the processing of personal data [39] and the Act of medical and health research [40]. The Data Protection Officer at Western Norway University of Applied Sciences evaluated that the survey was anonymous, and additional approval to invite students to participate was obtained from each University.

All statistical methods used are in accordance with The SAMPL Guidelines as required for Biomedical Journals.

\section{Consent for publication}

Not applicable

\section{Availability of data and materials}

Access to the dataset supporting the results reported will be made available by corresponding author on editor or reviewers' request. 


\section{Competing interests}

All authors declare no conflict of interest

\section{Funding}

Not applicable

\section{Authors' contributions}

All authors have made substantial contributions to all of the following: (1) the conception and design of the study, or acquisition of data, or analysis and interpretation of data, (2) drafting the article or revising it critically for important intellectual content, (3) final approval of the version to be submitted.

Conceptualization Flølo, TN, Gjeilo, KH, Andersen, JR, Haraldstad, K, Hjelmeland, IHH, Iversen, MM, Løyland, B, Norekvål, TM, Riiser, K, Rohde, G, Urstad, KH, Utne, I, Beisland, EG

Methodology Flølo, TN, Gjeilo, KH, Andersen, JR, Haraldstad, K, Hjelmeland, IHH, Iversen, MM, Løyland, B, Norekvål, TM, Riiser, K, Rohde, G, Urstad, KH, Utne, I, Beisland, EG

Validation $\quad$ Andersen JR, Beisland EG, Gjeilo KH

Formal analysis Flølo TN, Andersen JR

Investigation Flølo, TN, Gjeilo, KH, Andersen, JR, Haraldstad, K, Hjelmeland, IHH, Iversen, MM, Løyland, B, Norekvål, TM, Riiser, K, Rohde, G, Urstad, KH, Utne, I, Beisland, EG

Resources Flølo, TN, Gjeilo, KH, Andersen, JR, Haraldstad, K, Hjelmeland, IHH, Iversen, MM, Løyland, B, Norekvål, TM, Riiser, K, Rohde, G, Urstad, KH, Utne, I, Beisland, EG

Writing - Original Draft Flølo, TN

Writing - Review \& Editing Gjeilo, KH, Andersen, JR, Haraldstad, K, Hjelmeland, IHH, Iversen, MM, Løyland, B, Norekvål, TM, Riiser, K, Rohde, G, Urstad, KH, Utne, I, Beisland, EG

Visualization $\quad$ Flølo TN, Andersen JR, Beisland EG

Project administration Beisland EG

Acknowledgements Not applicable

\section{References}

1. Bryson WJ: Long-term health-related quality of life concerns related to the COVID-19 pandemic: a call to action. Qual Life Res 2021, 30(3):643-645. 
2. Nurunnabi M, Almusharraf N, Aldeghaither D: Mental health and well-being during the COVID-19 pandemic in higher education: Evidence from G20 countries. Journal of Public Health Research 2020, 9(Suppl 1):60-68.

3. Beisland EG, Gjeilo KH, Andersen JR, Bratås $\mathrm{O}, \mathrm{B} \emptyset \mathrm{B}$, Haraldstad K, Hjelmeland IHH, Iversen MM, Løyland B, Norekvål TM et al: Quality of life and fear of COVID-19 in 2600 baccalaureate nursing students at five universities: a cross-sectional study. Health and Quality of Life Outcomes 2021, 19(1):198.

4. NIPH: Norwegian Institute of Public Health. Quality of life and mental health during the COVID-19 pandemic november-december 2020.

https://www.fhi.no/div/helseundersokelser/fylkeshelseundersokelser/livskvalitet-og-psykisk-helseunder-koronaepidemien-nov-des-2020/. Accessed 5th Oct 2021. In.; 2020.

5. Pekmezovic T, Popovic A, Tepavcevic DK, Gazibara T, Paunic M: Factors associated with healthrelated quality of life among Belgrade University students. Qual Life Res 2011, 20(3):391-397.

6. Austin EJ, Saklofske DH, Mastoras SM: Emotional intelligence, coping and exam-related stress in Canadian undergraduate students. Aust J Psychol 2010, 62(1):42-50.

7. Saklofske DH, Austin EJ, Mastoras SM, Beaton L, Osborne SE: Relationships of personality, affect, emotional intelligence and coping with student stress and academic success: Different patterns of association for stress and success. Learning and Individual Differences 2012, 22(2):251-257.

8. Beiter R, Nash R, McCrady M, Rhoades D, Linscomb M, Clarahan M, Sammut S: The prevalence and correlates of depression, anxiety, and stress in a sample of college students. J Affect Disord 2015, 173:90-96.

9. Sanad HM: Stress and anxiety among junior nursing students during the initial clinical training: a descriptive study at College of Health Sciences, University of Bahrain. American Journal of Nursing Research 2019, 7(6):995-999.

10. Guldager JD, Jervelund SS, Berg-Beckhoff G: Academic stress in Danish medical and health science students during the COVID-19 lock-down. Dan Med J 2021.

11. Martirosyan N: An examination of factors contributing to student satisfaction in Armenian higher education. International Journal of Educational Management 2015, 29(2):177-191.

12. Alves $\mathrm{H}$, Raposo M: Conceptual model of student satisfaction in higher education. Total Quality Management 2007, 18(5):571-588.

13. Arambewela R, Hall J, Zuhair S: Postgraduate international students from Asia: Factors influencing satisfaction. Journal of Marketing for Higher Education 2006, 15(2):105-127.

14. Forrester S: An examination of the factors contributing to student satisfaction with their overall academic experience. Schole: A journal of leisure studies and recreation education 2006, 21(1):21-33.

15. Mai L-W: A comparative study between UK and US: The student satisfaction in higher education and its influential factors. Journal of marketing management 2005, 21(7-8):859-878.

16. Wiers-Jenssen J, Stensaker B, Grøgaard JB: Student satisfaction: Towards an empirical deconstruction of the concept. Quality in higher education 2002, 8(2):183-195. 
17. Li Z-S, Hasson F: Resilience, stress, and psychological well-being in nursing students: A systematic review. Nurse Educ Today 2020, 90:104440.

18. Savitsky B, Findling Y, Ereli A, Hendel T: Anxiety and coping strategies among nursing students during the covid-19 pandemic. Nurse Educ Pract 2020, 46.

19. Wong FKY, Liu H, Wang H, Anderson D, Seib C, Molasiotis A: Global nursing issues and development: Analysis of World Health Organization documents. J Nurs Scholarsh 2015, 47(6):574-583.

20. Keighley T: World Health Organization (WHO). The European Union Standards for Nursing and Midwifery: Information for Accession Countries. In., 2nd edn: Copenhagen: WHO Regional Office for Europe; 2009: 2-24.

21. Dewart G, Corcoran L, Thirsk L, Petrovic K: Nursing education in a pandemic: Academic challenges in response to COVID-19. Nurse Educ Today 2020, 92:2.

22. NOKUT: The Norwegian Agency for Quality Assurance in Education. The Student Survey. https://studiebarometeret.no/en/student/studieprogram/1175_syplgr/. Accessed 16th August 2021. In.; 2020.

23. Schmalbach B, Zenger M, Tibubos AN, Kliem S, Petrowski K, Brahler E: Psychometric Properties of Two Brief Versions of the Hopkins Symptom Checklist: HSCL-5 and HSCL-10. Assessment 2021, 28(2):617-631.

24. Levin KA, Currie C: Reliability and Validity of an Adapted Version of the Cantril Ladder for Use with Adolescent Samples. Social Indicators Research 2014, 119(2):1047-1063.

25. Iversen MM, Norekval TM, Oterhals K, Fadnes LT, Maeland S, Pakpour AH, Breivik K: Psychometric Properties of the Norwegian Version of the Fear of COVID-19 Scale. International Journal of Mental Health and Addiction 2021:1-19.

26. Strand BH, Dalgard OS, Tambs K, Rognerud M: Measuring the mental health status of the Norwegian population: A comparison of the instruments SCL-25, SCL-10, SCL-5 and MHI-5 (SF-36). Nordic Journal of Psychiatry 2003, 57(2):113-118.

27. Ruud N, Lovseth LT, Ro KI, Tyssen R: Comparing mental distress and help-seeking among first-year medical students in Norway: results of two cross-sectional surveys 20 years apart. Bmj Open 2020, 10(8).

28. Cantril H: The pattern of human concerns. New Brunswick, New Jersey: Reuters University Press. . In., edn.; 1965: 3-29.

29. Hjermstad MJ, Fayers PM, Bjordal K, Kaasa S: Using reference data on quality of life-the importance of adjusting for age and gender, exemplified by the EORTC QLQ-C30 (+3). Eur J Cancer 1998, 34(9):1381-1389.

30. Gelman A, Park DK: Splitting a Predictor at the Upper Quarter or Third and the Lower Quarter or Third. American Statistician 2009, 63(1):1-8.

31. Gelman A: Scaling regression inputs by dividing by two standard deviations. Stat Med 2008, 27(15):2865-2873. 
32. Cohen J: Statistical power analysis for the behavioural sciences, 2 nd edn: Hillsdate, NJ: Laurence Erlbaum Associates: Inc; 1988.

33. Lengetti E, Cantrell MA, DellaCroce N, Diewald L, Mensinger JL, Shenkman R: Learning environment and evidence among professionals and students satisfaction (LEAPS), experienced during the COVID-19 pandemic. Teaching and Learning in Nursing 2021, 16(4):342-346.

34. Sharma M, Adhikari T, Bhattarai T, Tulza K: Education Shift During COVID-19: Students' Satisfaction with Emergency Distance Learning. International Journal of Nursing Education 2021, 13(3).

35. Rossini S, Bulfone G, Vellone E, Alvaro R: Nursing Students' Satisfaction With The Curriculum: An Integrative Review. J Prof Nurs 2021.

36. Rodríguez-García MC, Gutiérrez-Puertas L, Granados-Gámez G, Aguilera-Manrique G, MárquezHernández VV: The connection of the clinical learning environment and supervision of nursing students with student satisfaction and future intention to work in clinical placement hospitals. $J$ Clin Nurs 2021, 30(7-8):986-994.

37. Ard N, Beasley SF, Nunn-Ellison K, Farmer S: Responding to the pandemic: Nursing education and the ACEN. Teaching and Learning in Nursing 2021, 16(4):292-295.

38. Michel A, Ryan N, Mattheus D, Knopf A, Abuelezam NN, Stamp K, Branson S, Hekel B, Fontenot HB: Undergraduate nursing students' perceptions on nursing education during the 2020 COVID-19 pandemic: A national sample. Nurs Outlook 2021.

39. Personal Data Act. The Norwegian Ministry of Justice. LOV-2018-06-15-38. https://lovdata.no/dokument/NL/lov/2018-06-15-38?q=personopplysningsloven. Accessed 6th December 2021.

40. Health Research Act. The Norwegian Minsty of Health and Care Services. LOV-1999-07-02-64. https://lovdata.no/dokument/NL/lov/1999-07-02-64?q=helsepersonelloven. Accessed 6th December 2021.

\section{Tables}

Table 1 Student characteristics associated with satisfaction with the educational curriculum

Multivariate binary logistic regression analysis with satisfaction with the educational curriculuma as the dependent variable 


\begin{tabular}{|c|c|c|c|c|c|c|c|c|}
\hline \multirow[b]{2}{*}{ Variables } & \multirow[b]{2}{*}{$\mathrm{n}(\%)$} & \multicolumn{4}{|c|}{ All students $(n=2605)$} & \multicolumn{3}{|c|}{$\begin{array}{l}\text { Students engaged in clinical } \\
\text { training ( } n=1591)\end{array}$} \\
\hline & & $\begin{array}{l}\text { Odds } \\
\text { ratio }\end{array}$ & $\begin{array}{l}95 \% \\
\text { Confidence } \\
\text { Interval }\end{array}$ & $\begin{array}{l}\mathrm{P}- \\
\text { value }\end{array}$ & $\begin{array}{l}\mathrm{n} \\
(\%)\end{array}$ & $\begin{array}{l}\text { Odds } \\
\text { ratio }\end{array}$ & $\begin{array}{l}95 \% \\
\text { Confidence } \\
\text { Interval }\end{array}$ & $\begin{array}{l}\mathrm{P}- \\
\text { value }^{\mathrm{c}}\end{array}$ \\
\hline University & & & & $\hat{0} .001$ & & & & $<.001$ \\
\hline NTNU ${ }^{b}$ & $\begin{array}{l}212 \\
(8)\end{array}$ & Ref. & & & $\begin{array}{l}126 \\
(8)\end{array}$ & Ref. & & \\
\hline Agder & $\begin{array}{l}396 \\
(15)\end{array}$ & 2.434 & $\begin{array}{l}1.399 \\
4.341\end{array}$ & & $\begin{array}{l}246 \\
(15)\end{array}$ & 5.541 & $\begin{array}{l}2.514 \\
12.209\end{array}$ & \\
\hline Stavanger & $\begin{array}{l}183 \\
(7)\end{array}$ & 0.734 & $\begin{array}{l}0.419 \\
1.288\end{array}$ & & $\begin{array}{l}115 \\
(7)\end{array}$ & 0.942 & $\begin{array}{l}0.452 \\
1.962\end{array}$ & \\
\hline $\begin{array}{l}\text { Western } \\
\text { Norway }\end{array}$ & $\begin{array}{l}873 \\
(34)\end{array}$ & 1.740 & $\begin{array}{l}1.098 \\
2.756\end{array}$ & & $\begin{array}{l}592 \\
(34)\end{array}$ & 2.841 & $\begin{array}{l}1.550 \\
5,209\end{array}$ & \\
\hline OsloMet & $\begin{array}{l}937 \\
(36)\end{array}$ & 1.156 & $\begin{array}{l}0.742 \\
1.801\end{array}$ & & $\begin{array}{l}512 \\
(36)\end{array}$ & 1.412 & $\begin{array}{l}0.790 \\
2.524\end{array}$ & \\
\hline $\begin{array}{l}\text { Number of } \\
\text { times tested } \\
\text { for COVID-19 }\end{array}$ & & & & 0.410 & & & & 0.236 \\
\hline Never & $\begin{array}{l}765 \\
(29)\end{array}$ & & & & $\begin{array}{l}403 \\
(25)\end{array}$ & & & \\
\hline 1 & $\begin{array}{l}724 \\
(28)\end{array}$ & 0.803 & $\begin{array}{l}0.553 \\
1.166\end{array}$ & & $\begin{array}{l}445 \\
(28)\end{array}$ & 0.902 & $\begin{array}{l}0.580 \\
1.403\end{array}$ & \\
\hline 2 & $\begin{array}{l}445 \\
(17)\end{array}$ & 1.160 & $\begin{array}{l}0.773 \\
1.741\end{array}$ & & $\begin{array}{l}292 \\
(18)\end{array}$ & 1.513 & $\begin{array}{l}0.911 \\
2.513\end{array}$ & \\
\hline 3 & $\begin{array}{l}326 \\
(12)\end{array}$ & 1.117 & $\begin{array}{l}0.772, \\
1.615\end{array}$ & & $\begin{array}{l}208 \\
(13)\end{array}$ & 1.399 & $\begin{array}{l}0.807 \\
2.424\end{array}$ & \\
\hline$\geq 4$ & $\begin{array}{l}346 \\
(13)\end{array}$ & 0.905 & $\begin{array}{l}0.659 \\
1.241\end{array}$ & & $\begin{array}{l}243 \\
(15)\end{array}$ & 0.660 & $\begin{array}{l}0.677 \\
1.851\end{array}$ & \\
\hline $\begin{array}{l}\text { Trust in } \\
\text { governmental } \\
\text { handling of } \\
\text { the COVID-19 } \\
\text { situation }\end{array}$ & & & & 0.063 & & & & 0.083 \\
\hline $\begin{array}{l}\text { Strongly } \\
\text { disagree }\end{array}$ & $\begin{array}{l}154 \\
(6)\end{array}$ & Ref. & & & $\begin{array}{l}90 \\
(6)\end{array}$ & Ref. & & \\
\hline Disagree & $\begin{array}{l}77 \\
(3)\end{array}$ & 0.602 & $\begin{array}{l}0.300 \\
1.208\end{array}$ & & $\begin{array}{l}40 \\
(3)\end{array}$ & 0.648 & $\begin{array}{l}0.253 \\
1.847\end{array}$ & \\
\hline $\begin{array}{l}\text { Neither } \\
\text { disagree nor }\end{array}$ & $\begin{array}{l}562 \\
(22)\end{array}$ & 0.932 & $\begin{array}{l}0.580 \\
1.499\end{array}$ & & $\begin{array}{l}312 \\
(20)\end{array}$ & 0.802 & $\begin{array}{l}0.417 \\
1.545\end{array}$ & \\
\hline
\end{tabular}




\begin{tabular}{|c|c|c|c|c|c|c|c|c|}
\hline Agree & $\begin{array}{l}1344 \\
(52)\end{array}$ & 1.257 & $\begin{array}{l}0.798, \\
1.981\end{array}$ & & $\begin{array}{l}847 \\
(53)\end{array}$ & 1.333 & $\begin{array}{l}0.714 \\
2.488\end{array}$ & \\
\hline $\begin{array}{l}\text { Strongly } \\
\text { agree }\end{array}$ & $\begin{array}{l}469 \\
(18)\end{array}$ & 1.169 & $\begin{array}{l}0.683 \\
2.000\end{array}$ & & $\begin{array}{l}302 \\
(19)\end{array}$ & 1.280 & $\begin{array}{l}0.606 \\
2.704\end{array}$ & \\
\hline $\begin{array}{l}\text { Trust in } \\
\text { universities' } \\
\text { handling of } \\
\text { the COVID-19 } \\
\text { situation }\end{array}$ & & & & $\begin{array}{l}< \\
0.001\end{array}$ & & & & $\begin{array}{l}< \\
0.001\end{array}$ \\
\hline $\begin{array}{l}\text { Strongly } \\
\text { disagree }\end{array}$ & $\begin{array}{l}181 \\
(7)\end{array}$ & Ref. & & & $\begin{array}{l}122 \\
(8)\end{array}$ & Ref. & & \\
\hline Disagree & $\begin{array}{l}447 \\
(17)\end{array}$ & 4.981 & $\begin{array}{l}3.288 \\
7.546\end{array}$ & & $\begin{array}{l}276 \\
(17)\end{array}$ & 4.773 & $\begin{array}{l}2.766 \\
8.234\end{array}$ & \\
\hline $\begin{array}{l}\text { Neither } \\
\text { disagree nor } \\
\text { agree }\end{array}$ & $\begin{array}{l}783 \\
(30)\end{array}$ & 15.215 & $\begin{array}{l}9.994 \\
23.163\end{array}$ & & $\begin{array}{l}475 \\
(30)\end{array}$ & 14.031 & $\begin{array}{l}8.035 \\
24.502\end{array}$ & \\
\hline Agree & $\begin{array}{l}982 \\
(38)\end{array}$ & 44.106 & $\begin{array}{l}\text { 27.394, } \\
71.012\end{array}$ & & $\begin{array}{l}584 \\
(37)\end{array}$ & 48.904 & $\begin{array}{l}\text { 25.468, } \\
93.908\end{array}$ & \\
\hline $\begin{array}{l}\text { Strongly } \\
\text { agree }\end{array}$ & $\begin{array}{l}213 \\
(8)\end{array}$ & 61.319 & $\begin{array}{l}27.014 \\
139.189\end{array}$ & & $\begin{array}{l}134 \\
(8)\end{array}$ & 164.892 & $\begin{array}{l}35.171 \\
773.086\end{array}$ & \\
\hline $\begin{array}{l}\text { Feeling lonely } \\
\text { due to COVID- } \\
19\end{array}$ & & & & 0.672 & & & & 0.670 \\
\hline $\begin{array}{l}\text { Strongly } \\
\text { disagree }\end{array}$ & $\begin{array}{l}164 \\
(6)\end{array}$ & Ref. & & & $\begin{array}{l}109 \\
(7)\end{array}$ & Ref. & & \\
\hline Disagree & $\begin{array}{l}380 \\
(15)\end{array}$ & 1.273 & $\begin{array}{l}0.686 \\
2.359\end{array}$ & & $\begin{array}{l}251 \\
(16)\end{array}$ & 1.075 & $\begin{array}{l}0.472, \\
2.446\end{array}$ & \\
\hline $\begin{array}{l}\text { Neither } \\
\text { disagree nor } \\
\text { agree }\end{array}$ & $\begin{array}{l}444 \\
(17)\end{array}$ & 1.388 & $\begin{array}{l}0.765, \\
2.517\end{array}$ & & $\begin{array}{l}292 \\
(18)\end{array}$ & 1.203 & $\begin{array}{l}0.542, \\
2.667\end{array}$ & \\
\hline Agree & $\begin{array}{l}899 \\
(34)\end{array}$ & 1.100 & $\begin{array}{l}0.638 \\
1.899\end{array}$ & & $\begin{array}{l}550 \\
(35)\end{array}$ & 0.973 & $\begin{array}{l}0.466 \\
2.029\end{array}$ & \\
\hline $\begin{array}{l}\text { Strongly } \\
\text { agree }\end{array}$ & $\begin{array}{l}718 \\
(28)\end{array}$ & 1.079 & $\begin{array}{l}0.616 \\
1.891\end{array}$ & & $\begin{array}{l}389 \\
(24)\end{array}$ & 1.310 & $\begin{array}{l}0.613 \\
2.801\end{array}$ & \\
\hline $\begin{array}{l}\text { Concerns } \\
\text { about the } \\
\text { quality of } \\
\text { education }\end{array}$ & & & & $\begin{array}{l}< \\
0.001\end{array}$ & & & & 0.001 \\
\hline $\begin{array}{l}\text { Strongly } \\
\text { agree }\end{array}$ & $\begin{array}{l}1196 \\
(46)\end{array}$ & Ref & & & & Ref & & \\
\hline Agree & 869 & 2.069 & 1.015 & & & 1.942 & 1.311, & \\
\hline
\end{tabular}


4.219

2.878

Neither

disagree nor

(11)

1.144 ,

4.435

3.097

1.405 ,

agree

Disagree

160

4.519

2.380,

1.467

0.658 ,

(6)

8.580

3.267

Strongly

disagree

$\begin{array}{lll}94 & 2.164 & 1.626 \\ (4) & & 2.879\end{array}$

3.622

1.266 ,

Fear of COVID-

19

(continuous z-

score)

\section{Clinical}

training during

0.689

the pandemic

Yes 1591 Ref.

(61)

No

$1014 \quad 1.042$

(39)

0.852 ,

1.275

\section{Concerns}

about high

absenteeism

during clinical

training

Strongly
agree

Agree

Neither

agree nor

disagree

Disagree

Strongly

disagree

Concerns

about the

completion of

clinical

training

Strongly

agree

Agree
810 Ref.

(51)

418

(26)

1.112

0.691 ,

1.791

138

(9)

1.277

0.642 ,

2.541

$\begin{array}{lll}119 & 3.051 & 1.205 \\ (7) & & 7.723\end{array}$

68

(4)

0.371

0.151 ,

0.910

935 Ref.

(59)

445

0.909

0.559, 
Neither agree nor disagree

Disagree

Strongly

disagree

Fewer learning

situations

during clinical

training

Strongly

agree

Agree

Neither

agree nor

disagree

Disagree

Strongly

disagree

Insufficient

guidance

during clinical

training

Strongly
agree

Agree

Neither

agree nor

disagree

Disagree

Strongly

disagree
93

(6)

0.610

0.278 ,

1.988

$50 \quad 0.631$

(3)

30

(2)

2.932

32
0.441
19.497

0.441
19.497

0.201 ,

1.988

476 Ref.

(30)

452
$(28)$

268

(17)

2.279

1.803

1.170,

2.778

(28)

1.359 ,

3.823

215

(14)

1.058

0.588 ,

$141 \quad 1.420 \quad 0.641$,

(9)

$141 \quad 1.420 \quad 0.641$,

1.903

3.146

195 Ref.

(12)

$264 \quad 1.174 \quad 0.684$,

(17)

2.012

396

(25)

1.427

0.838 ,

2.428

$434 \quad 1.465 \quad 0.831$,

(27)

2.583

$273 \quad 1.547$

0.778 ,

(17)

3.075

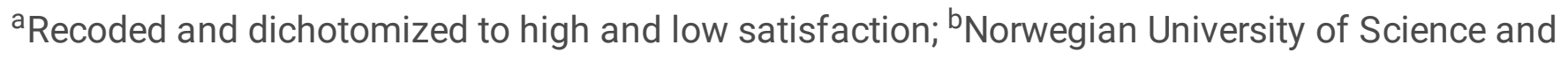
Technology; ${ }^{\mathrm{C} P}$-values below 0.05 in bold 
Table 2 Student characteristics associated with concerns about the quality of the nursing education

Multivariate binary logistic regression analysis with concerns about quality of the baccalaureate nursing education ${ }^{\mathbf{a}}$ as the dependent variable 


\begin{tabular}{|c|c|c|c|c|c|c|c|c|}
\hline \multirow[b]{2}{*}{ Variables } & \multirow[b]{2}{*}{$\mathrm{n}(\%)$} & \multicolumn{4}{|c|}{ All students $(n=2605)$} & \multicolumn{3}{|c|}{$\begin{array}{l}\text { Students engaged in clinical } \\
\text { training }(n=1591)\end{array}$} \\
\hline & & $\begin{array}{l}\text { Odds } \\
\text { ratio }\end{array}$ & $\begin{array}{l}95 \% \\
\text { Confidence } \\
\text { Interval }\end{array}$ & $\begin{array}{l}\mathrm{P}- \\
\text { value }\end{array}$ & n (\%) & $\begin{array}{l}\text { Odds } \\
\text { ratio }\end{array}$ & $\begin{array}{l}95 \% \\
\text { Confidence } \\
\text { Interval }\end{array}$ & $\begin{array}{l}\text { P- } \\
\text { value }^{c}\end{array}$ \\
\hline University & & & & 0.008 & & & & 0.047 \\
\hline$N T N U^{b}$ & $\begin{array}{l}212 \\
(8)\end{array}$ & Ref. & & & $\begin{array}{l}126 \\
(8)\end{array}$ & Ref. & & \\
\hline Agder & $\begin{array}{l}396 \\
(15)\end{array}$ & 0.775 & $\begin{array}{l}0.501 \\
1.199\end{array}$ & & $\begin{array}{l}246 \\
(15)\end{array}$ & 0.631 & $\begin{array}{l}0.345 \\
1.156\end{array}$ & \\
\hline Stavanger & $\begin{array}{l}183 \\
(7)\end{array}$ & 1.067 & $\begin{array}{l}0.618 \\
1.844\end{array}$ & & $\begin{array}{l}115 \\
(7)\end{array}$ & 1.060 & $\begin{array}{l}0.493 \\
2.277\end{array}$ & \\
\hline $\begin{array}{l}\text { Western } \\
\text { Norway }\end{array}$ & $\begin{array}{l}873 \\
(34)\end{array}$ & 1.337 & $\begin{array}{l}0.884 \\
2.022\end{array}$ & & $\begin{array}{l}592 \\
(34)\end{array}$ & 1.211 & $\begin{array}{l}0.688 \\
2.129\end{array}$ & \\
\hline OsloMet & $\begin{array}{l}937 \\
(36)\end{array}$ & 0.930 & $\begin{array}{l}0.617 \\
1.401\end{array}$ & & $\begin{array}{l}512 \\
(36)\end{array}$ & 0.918 & $\begin{array}{l}0.518 \\
1.626\end{array}$ & \\
\hline Year of study & & & & $\dot{0} 001$ & & & & $<0.001$ \\
\hline $1 \mathrm{st}$ & $\begin{array}{l}1073 \\
(41)\end{array}$ & Ref. & & & $\begin{array}{l}173 \\
(11)\end{array}$ & Ref. & & \\
\hline 2nd & $\begin{array}{l}800 \\
(31)\end{array}$ & 0.673 & $\begin{array}{l}0.461 \\
0.982\end{array}$ & & $\begin{array}{l}738 \\
(46)\end{array}$ & 0.636 & $\begin{array}{l}0.346 \\
1.171\end{array}$ & \\
\hline $3 r d$ & $\begin{array}{l}728 \\
(28)\end{array}$ & 0.416 & $\begin{array}{l}0.285 \\
0.606\end{array}$ & & $\begin{array}{l}680 \\
(43)\end{array}$ & 0.316 & $\begin{array}{l}0.171 \\
0.582\end{array}$ & \\
\hline Age category & & & & $\dot{0} 001$ & & & & 0.083 \\
\hline$<25$ & $\begin{array}{l}1845 \\
(71)\end{array}$ & Ref. & & & $\begin{array}{l}1075 \\
(68)\end{array}$ & Ref. & & \\
\hline $25-29$ & $\begin{array}{l}374 \\
(14)\end{array}$ & 0.708 & $\begin{array}{l}0.530 \\
0.945\end{array}$ & & $\begin{array}{l}262 \\
(16)\end{array}$ & 0.675 & $\begin{array}{l}0.463, \\
0.985\end{array}$ & \\
\hline $30+$ & $\begin{array}{l}382 \\
(15)\end{array}$ & 0.585 & $\begin{array}{l}0.445 \\
0.769\end{array}$ & & $\begin{array}{l}252 \\
(16)\end{array}$ & 0.754 & $\begin{array}{l}0.511 \\
1.112\end{array}$ & \\
\hline $\begin{array}{l}\text { Quarantine } \\
\text { status related to } \\
\text { COVID-19 }\end{array}$ & & & & 0.172 & & & & 0.223 \\
\hline Never & $\begin{array}{l}1302 \\
(50)\end{array}$ & Ref. & & & $\begin{array}{l}768 \\
(48)\end{array}$ & Ref. & & \\
\hline Present & $\begin{array}{l}49 \\
(2)\end{array}$ & 1.164 & $\begin{array}{l}0.939 \\
1.442\end{array}$ & & $\begin{array}{l}29 \\
(2)\end{array}$ & 3.216 & $\begin{array}{l}0.829 \\
12.475\end{array}$ & \\
\hline
\end{tabular}


Previous

$1255 \quad 1.901$

(48)

0.779 ,

4.644

794

0.994

0.739 ,

1.335

\section{Trust in governmental handling of the COVID-19 situation}

\begin{tabular}{|c|c|c|c|c|c|c|}
\hline $\begin{array}{l}\text { Strongly } \\
\text { disagree }\end{array}$ & $\begin{array}{l}154 \\
(6)\end{array}$ & Ref. & & $\begin{array}{l}90 \\
(6)\end{array}$ & Ref. & \\
\hline Disagree & $\begin{array}{l}77 \\
(3)\end{array}$ & 0.406 & $\begin{array}{l}0.180 \\
0.920\end{array}$ & $\begin{array}{l}40 \\
(3)\end{array}$ & 0.604 & $\begin{array}{l}0.181, \\
2.011\end{array}$ \\
\hline $\begin{array}{l}\text { Neither } \\
\text { disagree nor } \\
\text { agree }\end{array}$ & $\begin{array}{l}562 \\
(22)\end{array}$ & 0.552 & $\begin{array}{l}0.305 \\
0.998\end{array}$ & $\begin{array}{l}312 \\
(20)\end{array}$ & 0.575 & $\begin{array}{l}0.251 \\
1.381\end{array}$ \\
\hline Agree & $\begin{array}{l}1344 \\
(52)\end{array}$ & 0.693 & $\begin{array}{l}0.395 \\
1.216\end{array}$ & $\begin{array}{l}847 \\
(53)\end{array}$ & 0.713 & $\begin{array}{l}0.326 \\
1.559\end{array}$ \\
\hline Strongly agree & $\begin{array}{l}469 \\
(18)\end{array}$ & 0.679 & $\begin{array}{l}0.377 \\
1.225\end{array}$ & $\begin{array}{l}302 \\
(19)\end{array}$ & 0.690 & $\begin{array}{l}0.305, \\
1.559\end{array}$ \\
\hline
\end{tabular}

Trust in universities' handling of the COVID-19 situation

\begin{tabular}{llllllll}
$\begin{array}{c}\text { Strongly } \\
\text { disagree }\end{array}$ & $\begin{array}{l}181 \\
(7)\end{array}$ & Ref. & & $\begin{array}{l}122 \\
(8)\end{array}$ & Ref. & \\
\hline Disagree & 447 & 0.938 & 0.474, & 276 & 0.890 & 0.368, \\
& $(17)$ & & 1.854 & $(17)$ & & 2.152 \\
$\begin{array}{c}\text { Neither } \\
\text { disagree nor }\end{array}$ & 783 & 0.839 & 0.433, & 475 & 0.838 & 0.350, \\
agree & $(30)$ & & 1.627 & $(30)$ & & 2.004 \\
\hline Agree & 982 & 0.463 & 0.240, & & 584 & 0.521 & 0.217 , \\
& $(38)$ & & 0.892 & $(37)$ & & 1.253 \\
Strongly agree & 213 & 0.299 & 0.146, & 134 & 0.279 & 0.105, \\
& $(8)$ & & 0.613 & $(8)$ & & 0.744
\end{tabular}

\section{Feeling lonely}

due to

0.001

0.001

COVID-19

Strongly

disagree

Disagree

Neither
164 Ref.

(6)

$380 \quad 1.561 \quad 1.031$

(15)

2.362

$444 \quad 1.880 \quad 1.242$,

0.134

0.707 
disagree nor agree

Agree

Strongly agree

Satisfaction with the curriculum
718
$(28)$

(17)

2.847

3.252

2.183,

4.843

5.219

3.315,

8.215
(18)

3.152

$550 \quad 2.801 \quad 1.638$,

389

(24)
4.791

$\begin{array}{ll}5.555 & 2.934 \\ & 10.516\end{array}$

$<$

0.001

0.001

Strongly agree 274 Ref.

(11)

Agree

1108
$(43)$

731

Neither agree

nor disagree

Disagree

(28)

2.353

1.596

3.468

365

(14)

$5.161 \quad 2.927$

9.103

$128 \quad 2.081 \quad 1.038$

(5)

4.171

Strongly
disagree

Fear of COVID-19 (continuous Zscore)

Clinical training during the pandemic

$\begin{array}{llll}\text { Yes } & \begin{array}{l}1591 \\ (61)\end{array} & \text { Ref. } & \\ \text { No } & \begin{array}{l}1014 \\ (39)\end{array} & 0.773 & 0.545, \\ & & & 1.097\end{array}$

$2605 \quad 1.044 \quad 0.929$,
(100)

1.174

\section{Concerns about} getting infected

182 Ref.

(11)

$\begin{array}{lll}696 & 1.351 & 0.863, \\ (44) & & 2.115\end{array}$

$408 \quad 1.946 \quad 1.122$,

$225 \quad 3.909 \quad 1.815$,

(14) 8.419

$\begin{array}{lll}80 & 0.934 & 0.360, \\ (5) & & 2.419\end{array}$

during clinical

training

Strongly agree

0.150

1590

0.874

0.730 ,

1.046

0.141

(100)

1.046 


\begin{tabular}{|c|c|c|}
\hline disagree & (7) & 1.553 \\
\hline $\begin{array}{l}\text { Necessary } \\
\text { knowledge of }\end{array}$ & & 0.199 \\
\hline
\end{tabular}

Strongly agree

367 Ref.

(23)

Agree

$859 \quad 1.254 \quad 0.869$,

(54) $\quad 1.808$

Neither agree

nor disagree

$222 \quad 0.993 \quad 0.602$,

(14)

1.638

Disagree

$86 \quad 1.457 \quad 0.689$,

(5)

3.083

Strongly

19

disagree

(1)

0.412

0.137 ,

1.243

Concerns about

infecting others

during clinical

training

Strongly agree

788 Ref.

(50)

Agree

548

(34)

0.886

0.621 ,

1.265

Neither agree

nor disagree

$94 \quad 0.677 \quad 0.363$,

(6)

1.265

Disagree

$\begin{array}{lll}78 & 0.684 & 0.360 \text {, }\end{array}$

(5)

1.299

Strongly

disagree

45

(3)

$\begin{array}{ll}0.557 \quad 0.224 \\ & 1.384\end{array}$

Self-imposed

quarantine

during clinical

training

No

Yes

$\begin{array}{lll}712 & 1.142 & 0.843 \\ (47) & & 1.546\end{array}$

Concerns about

high

absenteeism

during clinical

training

Strongly agree

810 Ref. 
Agree

Neither agree nor disagree

Disagree

Strongly

disagree

Concerns about

completion of

clinical training

Strongly agree

Agree

Neither agree

nor disagree

Disagree

Strongly

disagree

Fewer learning

situations during

clinical training

Strongly agree

Agree

Neither agree

nor disagree

Disagree

Strongly

disagree

Insufficient

guidance during

clinical training

Strongly agree

$\begin{array}{lll}418 & 1.123 & 0.734, \\ (26) & & 1.716\end{array}$

$138 \quad 1.718 \quad 0.927$,

(9)

\begin{tabular}{lll}
119 & 1.485 & 0.796 \\
$(7)$ & & 2.769 \\
\hline 68 & 2.339 & 1.008 \\
$(4)$ & & 5.424
\end{tabular}

935 Ref.

(59)

$445 \quad 0.667 \quad 0.440$,

(28) $\quad 1.011$

$\begin{array}{lll}93 & 0.518 \quad 0.278\end{array}$

(6) 0.966

$\begin{array}{lll}50 & 0.242 & 0.111 \\ \text { (3) } & & 0.527\end{array}$

(3)

$30 \quad 0.271 \quad 0.095$,

(2) $\quad 0.771$ 


\begin{tabular}{|cccc|} 
Agree & 264 & 1.296 & 0.625 \\
& $(17)$ & & 2.684 \\
\hline Neither agree & 396 & 0.946 & 0.480 \\
nor disagree & $(25)$ & & 1.864 \\
\hline Disagree & 434 & 0.701 & 0.362 \\
& $(27)$ & & 1.358 \\
\hline Strongly & 273 & 0.915 & 0.448 \\
disagree & $(17)$ & & 1.870 \\
\hline
\end{tabular}

${ }^{a}$ Recoded and dichotomized into high and low levels of quality concerns; ${ }^{b}$ Norwegian University of Science and Technology; ${ }^{C}$-values below 0.05 in bold

Table 3 Hierarchical regression analysis of factors associated with psychological distress and overall quality of life in all students $(\mathrm{N}=\mathbf{2 6 0 5})$ 


\begin{tabular}{|c|c|c|c|c|c|c|c|}
\hline \multirow[b]{2}{*}{ Variable } & \multirow[b]{2}{*}{$\mathrm{n}(\%)$} & \multicolumn{3}{|c|}{ Psychological distress (SCL-5) ${ }^{a}$} & \multicolumn{3}{|c|}{ Overall quality of life } \\
\hline & & $\begin{array}{l}\text { Adjusted } \\
\text { coefficient }\end{array}$ & $\begin{array}{l}95 \% \\
\text { Confidence } \\
\text { Interval }\end{array}$ & $\begin{array}{l}\mathrm{P}- \\
\text { value }\end{array}$ & $\begin{array}{l}\text { Adjusted } \\
\text { coefficient }\end{array}$ & $\begin{array}{l}95 \% \\
\text { Confidence } \\
\text { Interval }\end{array}$ & $\begin{array}{l}\text { P- } \\
\text { value }\end{array}$ \\
\hline $\begin{array}{l}\text { Concerns } \\
\text { about the } \\
\text { quality of } \\
\text { education }\end{array}$ & & & & 0.031 & & & 0.722 \\
\hline $\begin{array}{l}\text { Strongly } \\
\text { agree }\end{array}$ & $\begin{array}{l}1196 \\
(46)\end{array}$ & Ref. & & & Ref. & & \\
\hline Agree & $\begin{array}{l}869 \\
(33)\end{array}$ & -0.06 & $-0.13,0.01$ & & 0.01 & $-0.06,0.09$ & \\
\hline $\begin{array}{l}\text { Neither } \\
\text { disagree nor } \\
\text { agree }\end{array}$ & $\begin{array}{l}287 \\
(11)\end{array}$ & -0.13 & $-0.24,-0.03$ & & -0.01 & $-0.12,0.10$ & \\
\hline Disagree & $\begin{array}{l}160 \\
(6)\end{array}$ & -0.15 & $-0.28,-0.02$ & & 0.05 & $-0.09,0.19$ & \\
\hline $\begin{array}{l}\text { Strongly } \\
\text { disagree }\end{array}$ & $\begin{array}{l}94 \\
(4)\end{array}$ & -0.17 & $-0.33,0.00$ & & 0.11 & $-0.06,0.29$ & \\
\hline $\begin{array}{l}\text { Satisfaction } \\
\text { with the } \\
\text { curriculum }\end{array}$ & & & & $<0.001$ & & & $<0.001$ \\
\hline $\begin{array}{l}\text { Strongly } \\
\text { agree }\end{array}$ & $\begin{array}{l}274 \\
(11)\end{array}$ & Ref. & & & Ref. & & \\
\hline Agree & $\begin{array}{l}1108 \\
(43)\end{array}$ & 0.06 & $-0.05,0.17$ & & -0.18 & $-0.30,-0.06$ & \\
\hline $\begin{array}{l}\text { Neither } \\
\text { disagree nor } \\
\text { agree }\end{array}$ & $\begin{array}{l}731 \\
(28)\end{array}$ & 0.16 & $0.03,0.18$ & & -0.37 & $-0.50,-0.24$ & \\
\hline Disagree & $\begin{array}{l}365 \\
(14)\end{array}$ & 0.25 & $0.11,0.40$ & & -0.56 & $-0.71,-0.41$ & \\
\hline $\begin{array}{l}\text { Strongly } \\
\text { disagree }\end{array}$ & $\begin{array}{l}128 \\
(5)\end{array}$ & 0.39 & $0.20,0.58$ & & -0.87 & $-1.07,-0.67$ & \\
\hline $\begin{array}{l}\text { Trust in } \\
\text { governmental } \\
\text { handling of the } \\
\text { COVID-19 } \\
\text { situation }\end{array}$ & & & & $<0.001$ & & & $\begin{array}{l}<.001 \\
0.00\end{array}$ \\
\hline $\begin{array}{l}\text { Strongly } \\
\text { disagree }\end{array}$ & $\begin{array}{l}154 \\
(6)\end{array}$ & Ref. & & & Ref. & & \\
\hline Disagree & $\begin{array}{l}77 \\
(3)\end{array}$ & -0.03 & $-0.24,0.18$ & & -0.11 & $-0.34,0.11$ & \\
\hline
\end{tabular}


Neither

disagree nor

agree

Agree

Strongly

agree

Trust in universities'

handling of the

COVID-19

situation

Strongly

disagree

Disagree

Neither

disagree nor

agree

Agree

Strongly

agree

Age category

$<25$

$30+$

\section{Feeling lonely} due to COVID-

19

Strongly

disagree

Disagree

Neither

disagree nor

agree

Agree
$562 \quad-0.16$

(22)

$1344 \quad-0.24$

(52)

$469 \quad-0.30$

(18)

$-0.30,-0.02$

0.06

$-0.09,0.20$

$-0.37,-0.11$

0.17

$0.04,0.31$

$-0.44,-0.16$

0.23

$0.08,0.39$

0.271

0.001

181 Ref.

(7)

$447 \quad 0.06$

(17)

$\begin{array}{ll}783 & 0.08\end{array}$

(30)

$982 \quad 0.01$

(38)

$213 \quad 0.10$

(8)

$-0.09,0.20$

$-0.18$

$-0.33,-0.02$

Ref.

$-0.06,0.23$

$-0.26$

$-0.41,-0.11$

$-0.13,0.16$

$-0.13$

$-0.29,0.02$

$-0.08,0.28$

$-0.27$

$-0.46,-0.08$

$<0.001$

0.030

1845 Ref

Ref.

(71)

377
(15)

$-0-14,0.03$

0.05

$-0.04,0.15$

382

$-0.23$

$-0.32,-0.15$

0.16

$0.07,0.25$

(15)

$<0.001$

$<0.001$

164 Ref.

(6)

$380 \quad 0.16$

(15)

$444 \quad 0.27$

(17)

$899 \quad 0.52$

(35)

$0.39,0.65$

$-0.80$

$-0.94,-0.66$ 


\begin{tabular}{|c|c|c|c|c|c|c|c|}
\hline $\begin{array}{l}\text { Strongly } \\
\text { agree }\end{array}$ & $\begin{array}{l}718 \\
(28)\end{array}$ & 0.95 & $0.82,1.09$ & & -1.35 & $-1.49,-1.20$ & \\
\hline $\begin{array}{l}\text { Fear of COVID- } \\
19 \text { (continuous } \\
\text { z-score) }\end{array}$ & $\begin{array}{l}2605 \\
(100)\end{array}$ & 0.47 & $0.43,0.51$ & $<0.001$ & -0.09 & $-0.13,-0.06$ & $<0.001$ \\
\hline $\begin{array}{l}\text { Risk of COVID- } \\
19\end{array}$ & & & & & & & 0.022 \\
\hline No & $\begin{array}{l}2089 \\
(80)\end{array}$ & & & & Ref. & & \\
\hline Uncertain & $\begin{array}{l}327 \\
(13)\end{array}$ & & & & -0.12 & $-0.22,-0.02$ & \\
\hline Yes & $\begin{array}{l}189 \\
(7)\end{array}$ & & & & -0.10 & $-0.23,0.02$ & \\
\hline
\end{tabular}

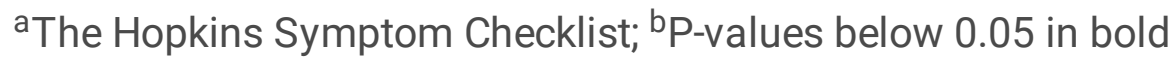

